\title{
Effects of inorganic nutrients, glucose and solar radiation on bacterial growth and exploitation of dissolved organic carbon and nitrogen in the northern Baltic Sea
}

\author{
Risto Lignell $^{1, *}$, Laura Hoikkala ${ }^{1,2}$, Titta Lahtinen ${ }^{1,2}$ \\ ${ }^{1}$ Finnish Institute of Marine Research, Erik Palménin aukio 1, PO Box 2, 00561 Helsinki, Finland \\ ${ }^{2}$ Present address: Tvärminne Zoological Station, J. A. Palménin tie 260, 10900 Hanko, Finland
}

\begin{abstract}
Factors controlling bacterial growth and degradation of dissolved organic carbon (DOC) and nitrogen (DON) in the productive surface layer were investigated during the main summer stages of phytoplankton growth in the Gulf of Finland. The effects of different combinations of ammonium, phosphate, glucose, flagellates, and sunlight pre-exposure treatments were followed for 2 to $3 \mathrm{wk}$ in natural bacterial $(<0.7 \mu \mathrm{m}$ pre-filtered) samples. Bacteria degraded the indigenous labile DOC and DON pools within 1 wk. The labile shares of total DOC and DON were $<1$ to 5 and 13 to $21 \%$, respectively, and their depletion showed no important treatment effects. Nevertheless, photochemical transformations of DOC and DON (sunlight pre-treatment over $1 \mathrm{~d}$ ) resulted in increased bacterial production. The phytoplankton system was N-limited in early summer, but showed a shift towards combined $\mathrm{P}$ and $\mathrm{N}$ deficiency during the late summer bloom of filamentous, $\mathrm{N}_{2}$-fixing cyanobacteria. Ambient labile DOC:DON ratios were low, increasing from $<1-3\left(\mathrm{~mol} \mathrm{~mol}^{-1}\right)$ in early summer to 3-7 in late summer, and addition of glucose led to a significant bacterial production response. Thus, it appears that bacteria were consistently limited by the low availability of labile DOC, while phytoplankton exhausted the available free mineral nutrient pools, thereby creating a situation combining C-limited bacterial growth with mineral nutrient-limited phytoplankton growth
\end{abstract}

KEY WORDS: DOC · DON · Bacteria - Bioassays · Photochemical degradation · Bacterial nutrition · Growth limitation $\cdot$ Baltic Sea

Resale or republication not permitted without written consent of the publisher

\section{INTRODUCTION}

The concentration of dissolved organic matter (DOM) in seawater exceeds by 1 to 2 orders of magnitude that of particulate organic matter, including living organisms and detritus (Williams 1995, Zweifel et al. 1995). Thus, the DOM pool is potentially important in nutrition of pelagic osmotrophs, like bacteria and algae, which are capable of exploiting dissolved organic substrates. Investigations of annual DOM dynamics have shown that both dissolved organic carbon (DOC) and nitrogen (DON) tend to accumulate in surface waters during periods of phytoplankton growth (Williams 1995, Zweifel et al. 1995). A review of studies on various aquatic environments suggested that on average, 14 to $19 \%$ of the total DOC pool is labile (LDOC) or easily degraded by bacteria (Søndergaard \& Middelboe 1995), and similar labile shares of total DON (LDON) have, for example, been recorded in the Baltic Sea (Jørgensen et al. 1999, Vähätalo \& Zepp 2005; for a review, see Berman \& Bronk 2003).

Pelagic bacteria play a central role in degrading allochthonous and autochthonous aquatic DOM pools, the latter being released from plankton food webs via autolysis, direct algal exudation, viral lysis, and 'sloppy' feeding by zooplankton (e.g. Lignell 1990, Thingstad et al. 1997, Azam 1998, Ward \& Bronk 2001, Berman \& Bronk 2003). It has been suggested that 
accumulation of LDOC and LDON in the productive surface layer depends on temperature or nutrient availability, which control bacterial growth rates, or the semi-labile nature of freshly produced DOM (Williams 1995, Zweifel et al. 1995, Thingstad \& Lignell 1997, Søndergaard et al. 2000). A broader scenario has also been suggested for labile DOM accumulation that would include a combination of grazing control of bacterial biomass by heterotrophic nanoflagellates and simultaneous limitation of bacterial production by either temperature (Zweifel 1999) or low mineral nutrient availability caused in turn by algal-bacterial competition for nutrients (Thingstad \& Lignell 1997, Thingstad et al. 1997).

In addition to biological (enzymatic) processes, solar radiation, especially UV radiation (280 to $400 \mathrm{~nm}$ ), transforms and degrades biologically recalcitrant DOM in surface waters (Moran \& Zepp 1997, Koopmans \& Bronk 2002, Vähätalo \& Wetzel 2004, Vähätalo \& Zepp 2005). The effect of sunlight exposure on bioavailability of DOM is determined by its origin and previous photochemical transformations (Obernosterer \& Benner 2004, Vähätalo \& Wetzel 2004). LDOC, LDON and inorganic $\mathrm{N}$ compounds released photochemically from the refractory DOM pool have been shown to stimulate bacterial growth (Moran \& Zepp 1997, Koopmans \& Bronk 2002, Vähätalo \& Zepp 2005). On the other hand, solar radiation may transform initially labile DOM molecules into more refractory compounds (Obernosterer et al. 2001), and since photochemical mineralization also has the potential for removing a marked share of biodegradable DOM (mainly as $\mathrm{CO}_{2}$ and $\mathrm{NH}_{3}$ ), competition between these processes is likely (Obernosterer \& Benner 2004).

Phytoplankton biomass responses in short-term (1 to $3 \mathrm{~d})$ nutrient treatment bioassays have suggested that most of the Baltic Sea is N-limited, rather than Plimited, excluding areas with a strong influence from riverine freshwater inputs and possibly periods of conspicuous blooms of $\mathrm{N}_{2}$-fixing filamentous cyanobacteria in late summer (Lignell et al. 1992, 2003, Kivi et al. 1993, and references therein). Thus, the large ambient DON pool is a potentially important nitrogen source for osmotrophic bacteria and algae in the Baltic Sea. Indeed, Eilola \& Stigebrandt (1999) challenged the view that nitrogen is limiting in the Baltic Sea, assuming in their mass balance calculations that the whole DON pool is eventually available for phytoplankton growth.

However, the aquatic DOM pool includes a continuum of compounds with increasing recalcitrance towards bacterial degradation (e.g. Zweifel et al. 1996, Azam 1998, Davis \& Benner 2007). Accordingly, Zweifel et al. (1996) found with a chemostat system that the rate of net bacterial DOC consumption de- creased 3 orders of magnitude with increasing residence time from 1 to $75 \mathrm{~d}$, showing 8 and $23 \%$ DOC declines, respectively. Bacterial DON degradation seems to follow a similar pattern in the Baltic Sea, with batch incubations showing, on average, $13 \%$ shortterm depletion (Jørgensen et al. 1999) and $<28 \%$ depletion over a 3.5 to 5 mo period (Vähätalo \& Zepp 2005). Solar radiation further decomposes biologically recalcitrant chromophoric DOM in the $1 \mathrm{~m}$ deep photolytic surface layer, but it was estimated that this process annually degraded only about $3 \%$ of total DON in the mixed $(0$ to $10 \mathrm{~m}$ ) layer in the Gulf of Finland (Vähätalo \& Zepp 2005). Thus, these results suggest that a major part of DON (and DOC) flushes out of the system, rather than fueling the plankton food web, and more work is evidently needed to settle the issue of which nutrient is primarily limiting in the Baltic Sea.

In the results reported here, indigenous bacterial $(<0.7 \mu \mathrm{m}$ pre-filtered) samples were used and different combinations of ammonium, phosphate, glucose, and flagellate treatments were applied along with sunlight pre-exposure of DOM to further define the factors controlling bacterial growth and nutrition in the Gulf of Finland (cf. Lignell et al. 1992, 2003, Kivi et al. 1993, Kuparinen \& Heinänen 1993). To our knowledge, this is the first report on DOM biodegradation bioassays done in the Baltic Sea where both LDOC and LDON pools have been measured simultaneously and directly, using the high temperature catalytic oxidation (HTCO) method.

\section{MATERIALS AND METHODS}

The experiments were carried out in the western Gulf of Finland (Tvärminne Zoological Station, University of Helsinki), and during a cruise on an east-west transect of the Gulf of Finland (RV 'Aranda', Finnish Institute of Marine Research) in 2001 and 2002. These experiments were done during the main summer stages of phytoplankton growth, including the post-spring bloom minimum period with low algal biomass and the late summer bloom of filamentous $\mathrm{N}_{2}$-fixing cyanobacteria (Table 1, Fig. 1) (cf. Niemi 1975, Lignell 1990). In July 2001 and 2002, the Tvärminne sampling sites were located in the outer archipelago-open sea zone south of the Tvärminne area (Längden and LL11; Fig. 1) (cf. Niemi 1975), whereas in June 2001, sampling could be carried out only $2 \mathrm{~km}$ south of the southernmost island of Långskär due to strong southerly winds. Nevertheless, all 3 samplings adequately represented the prevailing coastal situation, as the southerly storm evidently brought surface water from the open sea to our Långskär sampling site in June 2001. 


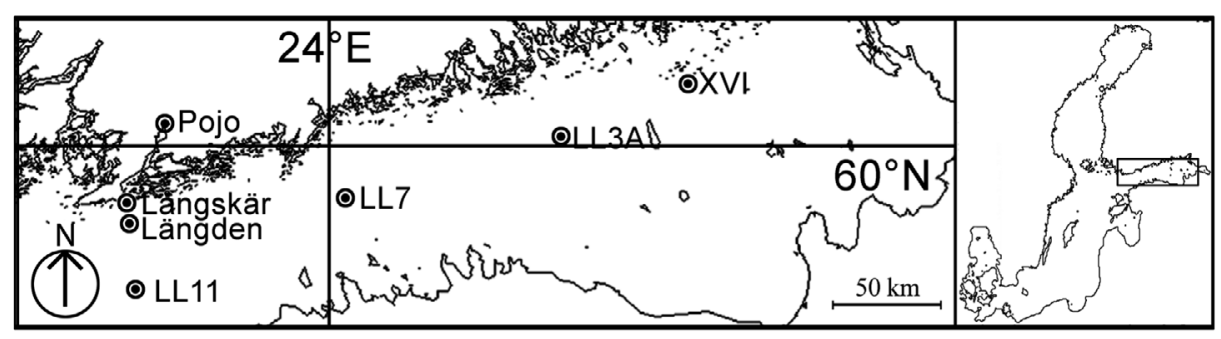

Fig. 1. Sampling sites in the Gulf of Finland, the northern Baltic Sea. Sampling for Tvärminne experiments was done on 14 June 2001 (Långskär), 4 July 2001 (Längden), and 17 July 2002 (LL11). Stns LL3A, XVI and LL7 were visited during the RV 'Aranda' cruise at the end of July 2001, while storage effects on DOM samples were studied at Stns Pojo, Längden and LL11 during July to September 2002

The Tvärminne area is not directly affected by large sewage outlets, but frequent upwellings during westerly winds (Niemi 1975, Laanemets et al. 2004) and atmospheric deposition (see Vähätalo \& Zepp 2005) introduce nutrients to the productive surface layer. The physics, chemistry, and plankton succession of the study area are well known (e.g. Niemi 1975, Lignell 1990, Kivi et al. 1993 and references therein). In summer, the water column is stratified with a thermocline at 10 to $15 \mathrm{~m}$ depth and salinity of 6 to $8 \%$. The coastal and open sea study sites in the eastern part of the Gulf of Finland (visited during the RV 'Aranda' cruise) (Fig. 1) are in turn more eutrophied due to anthropogenic nutrient load from the rivers Kymijoki and Neva.

Experimental design. On 14 June and 4 July 2001 and 17 July 2002, 3 experiments on the effects of mineral nutrient ( $\mathrm{N}$ and $\mathrm{P}$ ) and glucose $(\mathrm{C})$ treatments on bacterial growth and DOM degradation were carried out in the Tvärminne area (Table 1, Fig. 1). In addition,

Table 1. Experimental design on factors controlling time courses of bacterial growth and degradation of dissolved organic matter (DOM) in Tvärminne area (Tvä) and on an east-west transect (Cruise) in the Gulf of Finland in summer 2001 and 2002 (sampling dates given in parentheses). Nut or Sun = experiments without or with $1 \mathrm{~d}$ sunlight (vs. dark) pre-treatment; $\mathrm{N}=7.1 \mu_{\mathrm{mol} \mathrm{NH}}{ }_{4}^{+} \mathrm{l}^{-1} ; \mathrm{P}=$ $1.4 \mu \mathrm{mol} \mathrm{PO}_{4}{ }^{3-} \mathrm{l}^{-1} ; \mathrm{C}=83 \mu \mathrm{mol}$ glucose- $\mathrm{C}^{-1}$; Control = no N, P or C additions; Flag $=<5 \mu \mathrm{m}$ inoculum $(10 \% \mathrm{vol} / \mathrm{vol}$, including heterotrophic nanoflagellates $)$; $\mathrm{NP}^{*}=$ net $<0.2 \mu \mathrm{m}$ pre-filtered sample with $<0.8 \mu \mathrm{m}$ inoculum and $\mathrm{N}+\mathrm{P}$ treatment $;+/-=$ treatment carried out or not ( 5 replicate 11 bottles per treatment)

\begin{tabular}{|c|c|c|c|c|c|}
\hline $\begin{array}{r}\text { Treatment Tva } \\
(14 \mathrm{Jv}\end{array}$ & $\begin{array}{l}\text { ä, Nut } \\
\text { un 2001) }\end{array}$ & $\begin{array}{l}\text { Tvä, Nut } \\
\text { (4 Jul 2001) }\end{array}$ & $\begin{array}{l}\text { Tvä, Sun } \\
\text { (4 Jul 2001) (30 }\end{array}$ & $\begin{array}{l}\text { Cruise, Sun } \\
\text { Jun-1 Aug 2001) }\end{array}$ & $\begin{array}{l}\text { Tvä, Nut } \\
\text { (17 Jul 2002) }\end{array}$ \\
\hline Sun (vs. Dark) & - & - & $+(-)$ & $+(-)$ & - \\
\hline Control & - & - & + & - & + \\
\hline $\mathrm{N}$ & - & - & - & - & + \\
\hline $\mathrm{P}$ & - & + & - & - & + \\
\hline NP & - & + & - & - & + \\
\hline $\mathrm{NP}^{*}$ & + & - & + & + & - \\
\hline $\mathrm{PC}$ & - & + & - & - & + \\
\hline $\mathrm{NP}+\mathrm{C}(7 \mathrm{~d})$ & + & + & - & - & - \\
\hline Flag & - & - & + & - & - \\
\hline NP+Flag & - & + & - & - & - \\
\hline
\end{tabular}

the importance of photochemical DOM transformations (sunlight pre-exposure) and flagellate grazing in controlling these processes in the Tvärminne area was studied on 4 July 2001. Finally, the Tvärminne data on sunlight pre-treatment effects were supplemented by 3 experiments done during the Gulf of Finland cruise at the end of July 2001

The experiments were designed to create extreme Climited (N+P treatment) and N-limited (P treatment) conditions to maximise bacterial degradation of the LDOC and LDON pools, respectively (cf. Thingstad \& Lignell 1997). When selecting the appropriate treatment combinations, we assumed that the early summer minimum period was N-limited, and the late summer cyanobacterial bloom showed combined $\mathrm{N}$ and $\mathrm{P}$ deficiency (Table 1) (cf. Lignell et al. 2003 and references therein). In all experiments, surface samples (0 to $10 \mathrm{~m}$ ) were pooled in acid-washed plastic containers in dark conditions and subsequent sample processing was carried out in climate-controlled rooms with in situ temperatures. Samples including natural bacterial assemblages (grazers removed by $<0.7 \mu \mathrm{m}$ prefiltering; GF/F glass fibre filters or 75 SPF filter cartridges, Whatman) or both bacteria and flagellates $(<5 \mu \mathrm{m}$ pre-filtered inoculum, $10 \% \mathrm{vol} / \mathrm{vol}$; Poretics PC filters) were dispensed into 11 glass incubation bottles. The bottles were then treated with different combinations of $\mathrm{N}\left(7.1 \mu \mathrm{mol} \mathrm{NH}_{4}^{+}-\mathrm{N} \mathrm{l}^{-1}\right), \mathrm{P}$ $\left(1.4 \mu \mathrm{mol} \mathrm{PO}_{4}{ }^{3-}-\mathrm{P} \mathrm{l}^{-1}\right)$ and $\mathrm{C}(83 \mu \mathrm{mol}$ glucose-C $\mathrm{I}^{-1}$ ) with 5 replicates per treatment (Table 1).

DOM biodegradation incubations were carried out in darkened water baths (in situ temperature), and all treatments were done at the start of incubations (sampling day or Day 0), except for glucose addition on Day 7 to $\mathrm{NP}+\mathrm{C}(7 \mathrm{~d})$ samples (including NP 
treatment on Day 0). After overnight storage of the samples at $+3^{\circ} \mathrm{C}$, the importance of photochemical transformations for bioavailability of DOM was studied by exposing particle-free DOM samples $(<0.2 \mu \mathrm{m}$ pre-filtered; Vacucap 90 PF filters, Gelman) in $250 \mathrm{ml}$ quartz bottles to natural sunlight over a sunny day at $0.2 \mathrm{~m}$ depth (with corresponding dark samples as controls). These samples were then inoculated with natural bacteria $(<0.8 \mu \mathrm{m}$ pre-filtered inoculum, $10 \% \mathrm{v} / \mathrm{v}$; Poretics PC filters) and treated with different combinations of nutrients and flagellates at the start of incubations (Table 1).

Contamination precautions. To avoid the contamination problems that are notorious in DOM measurements, the procedures outlined by Sharp et al. (1993) were followed with slight modifications. Briefly, metallic parts inside our 71 Sormunen sampler were covered with Teflon and the sampler's metal screws were changed to nylon screws. The sampler was rinsed with hydrochloric acid $(\mathrm{HCl})$ followed by Milli-Q water before use. All quartz- and glassware, glass fibre filters and PC bottles were placed for at least for $2 \mathrm{~h}$ in $15 \%$ $\mathrm{HCl}$ and subsequently rinsed carefully with tap water, Milli-rho and Milli-Q water. In addition, quartz glass bottles, glassware and glass fibre filters were heated to $400^{\circ} \mathrm{C}$ for at least $4 \mathrm{~h}$. All containers and sample bottles were thoroughly rinsed with sample water before use.

Nutrients. Mineral nutrient (soluble reactive phosphorus [SRP], $\mathrm{NO}_{3}{ }^{-}$and $\mathrm{NH}_{4}{ }^{+}$), and total $\mathrm{N}$ and $\mathrm{P}$ concentrations were measured according to Grasshoff et al. (1983) from separate incubation bottle sets treated similarly to those used for the corresponding DOM biodegradation samples (Table 1).

Both DOC and TDN concentrations were measured by HTCO method using a Shimadzu TOC-V CPH carbon and nitrogen analyser. Sub-samples $(<0.45 \mu \mathrm{m}$ Supor Acrodisc PES filter, Gelman Sciences) were stored in a freezer $\left(-20^{\circ} \mathrm{C}\right.$, Year 2001), or acidified to $\mathrm{pH} 2.5$ with $2 \mathrm{~N} \mathrm{HCl}$ and stored in darkness at room temperature (Year 2002). The $20 \mathrm{ml}$ glass ampoules were stored for 4 to 12 mo. The DOC and TDN analyses, including calibration and rinsing steps, and randomised sample run order, followed the procedures described by Sharp et al. (1993). DON concentrations were calculated from TDN values by subtracting concomitant mineral N concentrations.

Storage effects on DOM samples. The DOC and DON analyses were delayed by 4 to $12 \mathrm{mo}$, and hence we tested the effect of storage time and method on the respective gains. Between 17 July and 23 September 2002, 5 samplings were carried out, where surface $(2 \mathrm{~m})$ samples were collected from 3 sites, including the freshwater end of a nearby fjord (Pojo Bay), and our 2 open-sea stations (Längden and LL11) (Fig. 1). Parallel DOC and total dissolved nitrogen (TDN) sub-sample sets (with 3 replicates) were either frozen (like the 2001 samples) or acidified $(\mathrm{pH}$ 2.5; like the 2002 samples) and stored for $1 \mathrm{yr}$, while a third set was acidified and measured within $2 \mathrm{wk}$.

After 1 yr of storage of the open-sea samples, neither acidification nor freezing preservation caused significant problems or unexpected DOC gains or losses (Tukey's test, p > 0.05) (Table 2). The same was true with frozen TDN samples, but acidification storage led to a significant (on average $6 \%$ ) increase in TDN gains (Tukey's test, $\mathrm{p}<0.05$ ). Though we were not able to identify the cause of the TDN increase, ammonia and volatile organic amine contamination via air seem plausible sources of extra $\mathrm{N}$ in the acidified samples (cf. Sharp et al. 1993). Unfortunately, the mid-July 2002 DOM samples were stored acidified, and a ca. $0.5 \mathrm{yr}$ delay between analysis of the samples from Days 0 and 1 and later phases of incubations seemed to cause a systematic bias or unfounded temporal TDN and DON increases (data not shown).

In addition, we estimated the uncertainty of the DOC and TDN values obtained by the HTCO method. After exclusion of the 4 DOC and 4 DON outliers due to contamination (Grubbs' test), an ANOVA with 3-way factorial design was carried out (non-transformed data), including the main effects of the study sites, sampling dates and storage methods, and all their interactions. Measurement uncertainty $(\mathrm{CV})$ was then extracted from the residuals of the ANOVA table $(\mathrm{CV}=100 \times$ [mean square of residuals] ${ }^{0.5} /$ grand mean), giving CVs of 2.3 and $4.8 \%$ for DOC and TDN measurements, respectively. As the inorganic $\mathrm{N}$ pool accounts for a

Table 2. Effect of storage for 1 yr of acidified or frozen samples vs. short ( $<2 \mathrm{wk}$ ) acid-preservation on gains of DOC and TDN by the HTCO method in freshwater (Pojo Bay) and open sea (Längden and LL11) samples collected in the western Gulf of Finland. Between 17 July and 23 September 2002, 5 samplings took place and their mean values $\left(\mu \mathrm{mol} \mathrm{l}{ }^{-1}\right)$ are given along with mean ratios of samples stored for $1 \mathrm{yr}$ to corresponding contemporaneous samples measured within 2 wk (\%, in brackets). Study sites are shown in Fig. 1

\begin{tabular}{|lcccc|}
\hline Variable & Site & $\begin{array}{c}\text { Acid, short } \\
\text { mean }(\mathrm{CV})\end{array}$ & $\begin{array}{c}\text { Acid, 1 yr } \\
\text { mean }(\% \text { short, CV) }\end{array}$ & $\begin{array}{c}\text { Freezer, 1 yr } \\
\text { mean }(\% \text { short, CV) }\end{array}$ \\
\hline DOC & Pojo & $644(2)$ & $676(105,3)$ & $639(99,3)$ \\
$\left(\mu \mathrm{mol} \mathrm{C} \mathrm{^{-1 } )}\right.$ Längden & $403(4)$ & $402(100,4)$ & $403(100,4)$ \\
& LL11 & $408(3)$ & $405(99,2)$ & $413(101,6)$ \\
TDN & Pojo & $37.0(7)$ & $41.9(113,4)$ & $39.7(108,3)$ \\
$\left(\mu \mathrm{mol} \mathrm{N} \mathrm{l^{-1 } )}\right.$ Längden & $19.9(3)$ & $21.4(106,6)$ & $20.4(103,2)$ \\
& LL1 & $19.3(2)$ & $20.5(106,5)$ & $19.4(100,7)$ \\
\hline
\end{tabular}


small proportion of TDN in our $\mathrm{N}$-deficient summer plankton system, our TDN uncertainty estimate also applies to DON measurements in these surface samples.

Microscopy. Bacteria and heterotrophic nanoflagellates were counted from 2 replicate incubation bottles of each treatment. The samples were killed with glutaraldehyde (final concentration 5\%) and bacterial samples were stained with acridine orange and flagellate samples with proflavine (Hobbie et al. 1977, Haas 1982). The samples were counted with epifluorescence microscopy (Leitz Aristoplan microscope). Large (>2 $\mu \mathrm{m}$ ) algae were preserved with acid Lugol's solution (final concentration ca. $0.3 \%$ ). The samples were counted according to the method of Utermöhl (1958), using phase contrast microscopy.

Cell volumes of bacteria were measured using digital image analysis (Massana et al. 1997) and flagellate cell volumes by epifluorescence microscopy. Bacterial C biomass was estimated from measured biovolumes using

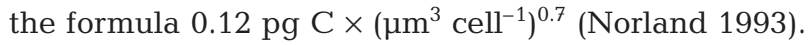
Flagellate $\mathrm{C}$ biomass was estimated using the conversion coefficient $0.22 \mathrm{pg} \mathrm{C} \mu^{-3}$ (Børsheim \& Bratbak 1987),

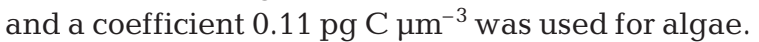

Bacterial production. Bacterial production was measured with a modification of the ${ }^{3} \mathrm{H}$-thymidine (TdR) method with cold TCA extraction, where separation of cells from liquid phase was done in ice-cold conditions by centrifugation instead of filtration (cf. Riemann et al. 1987, Smith \& Azam 1992). Duplicate sub-samples (1 $\mathrm{ml}$ each) from all DOM incubation bottles (5 replicates per treatment) and 2 formalin-killed blanks per treatment were dispensed in sterilised Eppendorf tubes with ${ }^{3} \mathrm{H}$-thymidine (specific activity ca. $80 \mathrm{Ci}$ $\mathrm{mmol}^{-1}, 20 \mathrm{nM}$ final concentration, NEN, Perkin Elmer) and incubated at in situ temperature for $1 \mathrm{~h}$. Net bacterial production was estimated using measured mean bacterial cell volumes and conversion factors which were calculated cumulatively for each treatment (cells produced per integral ${ }^{3} \mathrm{H}$-thymidine incorporation; Bjørnsen \& Kuparinen 1991).

Statistical tests of treatment effects. In all tests the normality of the data and residuals was confirmed by a Shapiro-Wilk test, and log transformation was used when appropriate. Net integral bacterial production responses over the initial ca. 1 wk production stimulation periods (trapezoid integration, start values subtracted) and biomass increase from start to peak values (net growth) were calculated separately for each replicate incubation bottle, and the statistical importance of treatment effects on these biological responses were extracted with 2-way ANOVA (no significant bottle effects were found). Significant treatment effects revealed by ANOVA were then sorted out with either Tukey's test or linear contrasts (Scheffé's F).
The labile shares of ambient DOC and DON pools within each treatment set were estimated by linear regressions fitted to the initial ca. $1 \mathrm{wk}$ declining periods of DOC and DON (5 replicate incubation bottles and daily measurements). LDOC and LDON pools were then calculated using the slope of the regression line, and their respective percentage shares of total pools were calculated based on the Day 0 (intercept) value.

\section{RESULTS}

\section{Initial conditions}

During the summer minimum period from mid-June to early July 2001, the biomass of large (>2 $\mu \mathrm{m}$ ) phytoplankton was relatively low south of the Tvärminne archipelago, but increased during that period from 9

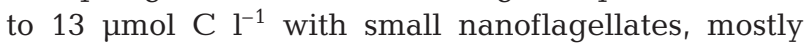
belonging to Chrysophyceae and Prymnesiophyceae. The increase in phytoplankton abundance was accompanied by a decrease of Secchi depth from a typically high post-spring bloom value of 8.0 to $5.9 \mathrm{~m}$, and the bacterial biomass increased from 2.4 to $5.3 \mu \mathrm{mol} \mathrm{C} \mathrm{l}^{-1}$. By the end of July 2001, a moderate bloom of filamentous cyanobacteria occurred in the Gulf of Finland (RV 'Aranda' cruise). The total biomass of large algae ranged from 4 to $14 \mu \mathrm{mol} \mathrm{C}{ }^{-1}$ with 39 to $85 \%$ of this community being the filamentous cyanbobacterial species Nodularia spumigena Mertens ex Bornet et Flahault 1886 and Aphanizomenon flos-aquae Ralfs ex Bornet et Flahault 1886. In mid-July 2002, sampling in the Tvärminne area was again conducted during a conspicuous bloom of filamentous cyanobacteria $(N$. spumigena, A. flos-aquae, Anabaena lemmermannii P. Richter in Lemmermann 1903) and small flagellates (Prasinophyceae, Chrysophyceae, Prymnesiophyceae and Cryptophyceae). The bloom showed high algal

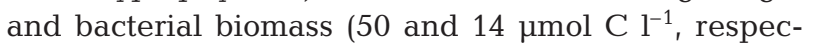
tively), and accordingly, it was accompanied by a low Secchi depth $(2.1 \mathrm{~m})$.

In early summer 2001, the surface concentrations of mineral $\mathrm{N}$ were low in the Tvärminne area, whereas SRP was still available (Table 3). By the end of July 2001, both mineral $\mathrm{N}$ and $\mathrm{P}$ pools were close to the limit of detection for samples obtained during the east-west cruise, except for $\mathrm{N}$ in the sample from Stn XVI (Fig. 1). Accordingly, the inorganic N:P ratios increased markedly from early to late summer (from 2 to 66 in the western Gulf of Finland). During the cyanobacterial bloom in mid-July 2002, consistent moderate southwest-west winds (5 to $10 \mathrm{~m} \mathrm{~s}^{-1}$ over 6 d) prevailed in the Tvärminne area, causing an upwelling of nutrient-rich deep water, and both min- 
Table 3. Ambient temperature and nutrient concentrations in surface samples at study sites in the Gulf of Finland in summer 2001 and 2002. Cru = RV 'Aranda' cruise stations; $\mathrm{SRP}=$ soluble reactive phosphorus; DIN:SRP = inorganic N:P ratio. Other explanations in Table 1, Fig. 1

\begin{tabular}{|c|c|c|c|c|c|c|c|c|c|c|}
\hline $\begin{array}{l}\text { Sampling } \\
\text { date }\end{array}$ & Study site & $\begin{array}{l}\text { Temp. } \\
\left({ }^{\circ} \mathrm{C}\right)\end{array}$ & $\begin{array}{c}\mathrm{NH}_{4}^{+}-\mathrm{N} \\
\left(\mathrm{nmol} \mathrm{l}^{-1}\right)\end{array}$ & $\begin{array}{c}\mathrm{NO}_{3}^{-}-\mathrm{N} \\
\left(\mathrm{nmol} \mathrm{l}^{-1}\right)\end{array}$ & $\begin{array}{c}\mathrm{SRP} \\
\left(\mathrm{nmol} \mathrm{l}^{-1}\right)\end{array}$ & $\begin{array}{c}\text { DIN:SRP } \\
\left(\mathrm{mol} \mathrm{mol}^{-1}\right)\end{array}$ & $\begin{array}{c}\text { Total N } \\
\left(\mu \mathrm{mol} \mathrm{l}^{-1}\right)\end{array}$ & $\begin{array}{c}\text { Total P } \\
\left(\mu \mathrm{mol} \mathrm{l}^{-1}\right)\end{array}$ & $\begin{array}{c}\text { DOC } \\
\left(\mu \mathrm{mol} \mathrm{l}^{-1}\right)\end{array}$ & $\begin{array}{c}\text { DON } \\
\left(\mu \mathrm{mol} \mathrm{l}^{-1}\right)\end{array}$ \\
\hline 14 Jun 2001 & Tvärminne & 10 & 171 & 229 & 242 & 1.7 & 15.7 & 0.548 & 383 & 18.6 \\
\hline 4 Jul 2001 & Tvärminne & 13 & 229 & 86 & 142 & 2.2 & 20.7 & 0.510 & 383 & 17.9 \\
\hline 30 Jul 2001 & Cru LL3A & 21 & 236 & 79 & 3 & 97 & 27.9 & 0.319 & 475 & 22.1 \\
\hline 31 Jul 2001 & Cru XVI & 19 & 786 & 350 & 13 & 88 & 25.7 & 0.448 & 483 & 22.1 \\
\hline 1 Aug 2001 & Cru LL7 & 18 & 164 & 50 & 3 & 66 & 23.6 & 0.435 & 433 & 20.7 \\
\hline 17 Jul 2002 & Tvärminne & 18 & 364 & 171 & 39 & 14 & - & - & 408 & 20.0 \\
\hline
\end{tabular}

eral $\mathrm{N}$ and $\mathrm{P}$ showed elevated concentrations compared to the late summer bloom in 2001. In contrast, the ambient DOC and DON concentrations in the western sampling sites were reasonably consistent throughout the study, ranging from 380 to 430 and 18 to $21 \mu \mathrm{mol} \mathrm{l} \mathrm{l}^{-1}$, respectively, with C:N ratios of 20 to 22 (Table 3).

\section{Mineral nutrient dynamics}

The fate of $\mathrm{N}$ and $\mathrm{P}$ treatments differed considerably between the 2 Tvärminne experiments done in early summer 2001. In June, depletion of ammonium and
SRP showed an initial 4 to 6 d delay in samples with NP treatment, after which all inorganic $\mathrm{N}$ and ca. $50 \%$ of $\mathrm{P}$ additions were depleted within 5 to $7 \mathrm{~d}$ (Fig. 2a,b). In early July, ammonium and SRP concentrations remained in turn reasonably consistent also in samples with combined NP treatment, and only glucose addition on Day 7 led to a clear depletion of initial mineral $\mathrm{N}$ and $\mathrm{P}$ additions in $\mathrm{NP}+\mathrm{C}(7 \mathrm{~d})$ samples (Fig. 2c,d).

The fate of nutrient treatments differed also between incubations done during the cyanobacterial blooms, in 2001 and 2002. During the cruise at the end of July 2001, N additions were not depleted at any of the 3 stations, while some added $\mathrm{P}$ (100 to $290 \mathrm{nmol} \mathrm{PO}_{4}{ }^{3-}$
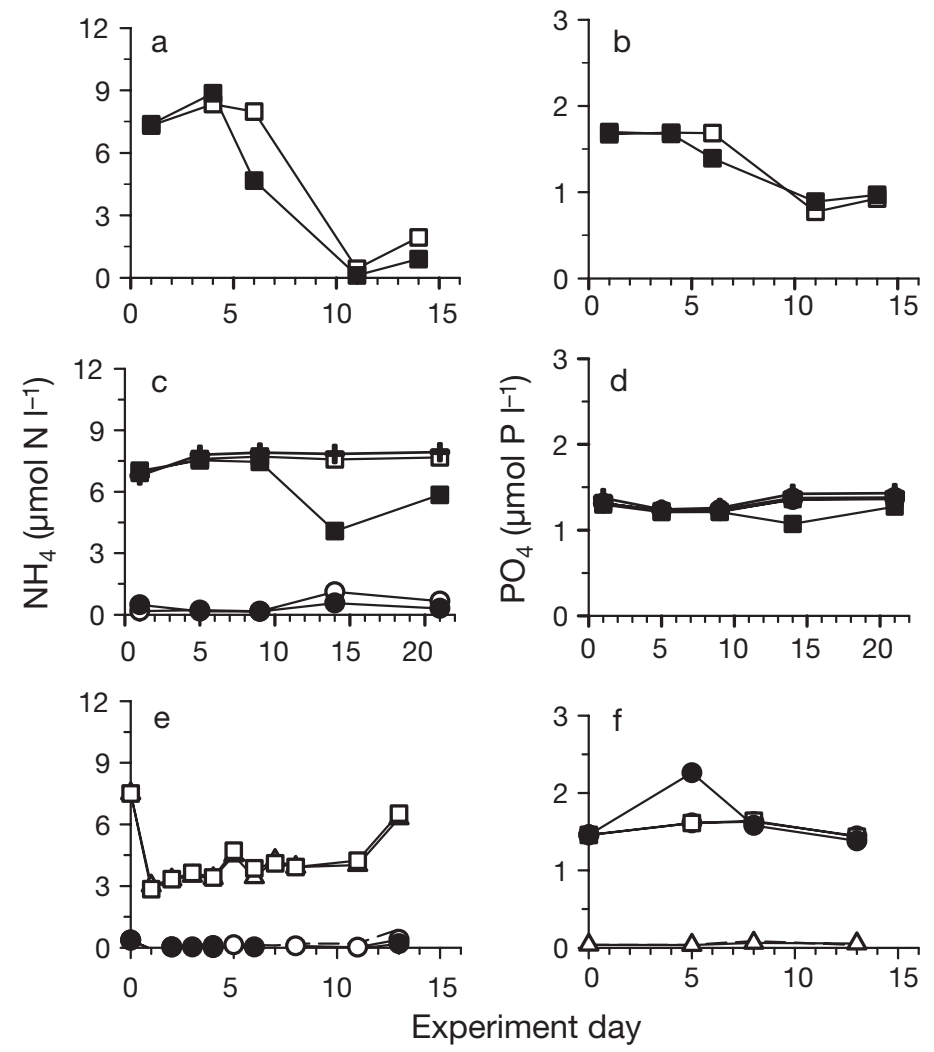
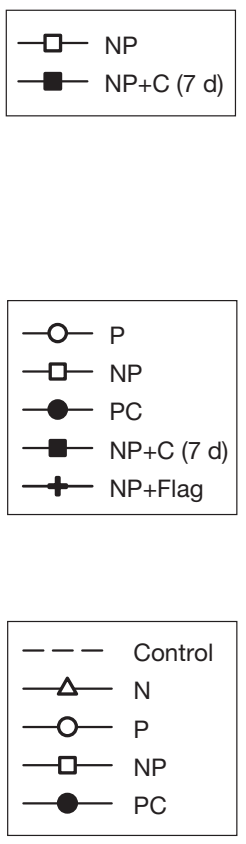

Fig. 2. Time courses of mineral nutrient concentrations $\left(\mathrm{NH}_{4}{ }^{+}\right.$and $\mathrm{PO}_{4}$ [soluble reactive phosphorus]) in DOM biodegradation incubations with different combinations of nutrient, glucose, and flagellate treatments. The experiments were carried out in Tvärminne (western Gulf of Finland) during the summer minimum period in 2001 (mid-June: a,b; early July: $\mathrm{c}, \mathrm{d}$ ) and during the bloom of filamentous cyanobacteria in 2002 (mid-July: e,f) 
Table 4. Labile shares of total DOC and DON (respective \%LDOC and \%LDON) in indigenous bacterial $(<0.7 \mu \mathrm{m}$ pre-filtered) samples treated with nutrients, heterotrophic nanoflagellates, and sunlight (vs. dark) pre-exposure. LDOC and LDON pools were estimated directly by fitting linear regressions to the initial ca. 1 wk declining periods of total DOC and DON (HTCO method). * Significant regression slopes in DOC and DON decline. In samples with glucose addition on Day 0 (PC), consumption of the extra glucose-C is included in the \%LDOC estimate (in brackets), whereas in NP+C (7 d) samples this was not the case (glucose-C added on Day 7). E-W GoF: east-west transect in the Gulf of Findland; -: missing values; Flag: see Table 1

\begin{tabular}{|c|c|c|c|c|c|}
\hline $\begin{array}{l}\text { Sampling } \\
\text { date }\end{array}$ & $\begin{array}{l}\text { Study } \\
\text { site }\end{array}$ & Treatment & $\%$ LDOC & $\%$ LDON & LDOC:LDON \\
\hline 14 Jun 2001 & Tvärminne & $\begin{array}{c}\mathrm{NP} \\
\mathrm{NP}+\mathrm{C}(7 \mathrm{~d})\end{array}$ & $\begin{array}{l}0.8 \\
0.2\end{array}$ & $\begin{array}{l}20^{*} \\
15^{*}\end{array}$ & $\begin{array}{l}0.8 \\
0.3\end{array}$ \\
\hline 4 Jul 2001 & Tvärminne & $\begin{array}{c}\mathrm{P} \\
\mathrm{NP} \\
\mathrm{PC} \\
\mathrm{NP}+\mathrm{C}(7 \mathrm{~d}) \\
\text { NP+Flag }\end{array}$ & $\begin{array}{c}1.8 \\
2.8^{*} \\
\left(4.4^{*}\right) \\
1.1 \\
2.6^{*}\end{array}$ & $\begin{array}{l}13^{*} \\
20^{*} \\
14^{*} \\
21^{*} \\
21^{*}\end{array}$ & $\begin{array}{c}3.1 \\
3.3 \\
(8.0) \\
1.1 \\
2.7\end{array}$ \\
\hline $\begin{array}{l}30 \mathrm{Jul}-1 \mathrm{Aug} \\
2001\end{array}$ & $\begin{array}{l}\text { Cruise on } \\
\text { E-W GoF }\end{array}$ & $\begin{array}{l}\text { Dark + NP } \\
\text { Sun + NP }\end{array}$ & $\begin{array}{l}2^{*}-4^{*} \\
3-5^{*}\end{array}$ & $\begin{array}{c}14^{*} \\
9^{*}-13^{*}\end{array}$ & $\begin{array}{l}3.5-7.2 \\
6.5-10\end{array}$ \\
\hline $17 \mathrm{Jul} 2002$ & Tvärminne & $\begin{array}{c}\text { Control } \\
\mathrm{N} \\
\mathrm{P} \\
\mathrm{NP} \\
\mathrm{PC}\end{array}$ & $\begin{array}{l}4.9^{*} \\
5.2^{*} \\
3.2^{*} \\
5.3^{*} \\
\left(13^{*}\right)\end{array}$ & $\begin{array}{l}- \\
- \\
- \\
- \\
-\end{array}$ & $\begin{array}{l}- \\
- \\
- \\
- \\
-\end{array}$ \\
\hline
\end{tabular}

(Table 4). After that, DON increased ca. $20 \%$ above the initial level in these samples, and the increase was accompanied by a corresponding depletion of added ammonium (Fig. 2a). In midJuly 2002, large (60\%) shares of ammonium additions were similarly depleted in the $\mathrm{N}$ and NP samples (Fig. 2e) and channeled into the DON pool within $24 \mathrm{~h}$.

In early July 2001, DON showed a declining trend in all treatment sets during the first week, and 13 to $21 \%$ of the DON pool was utilized within $7 \mathrm{~d}$ (Table 4). No important nutrient ( $\mathrm{N}$ or $\mathrm{P})$, glucose or flagellate treatment effects were recorded (comparison of linear regression slopes, $F$ test, $\mathrm{p}>$ 0.45) (Table 1). At the end of July 2001, labile DON accounted for 9 to $14 \%$ of total DON during the cruise.

Altogether, ambient labile DOC: DON ratios were low in 2001, increasing from $<1-3$ in the early summer Tvärminne samples to 3-7 in the late summer cruise samples with dark pre-treatment (excluding

$\mathrm{l}^{-1}$ ) was depleted in both sunlight and dark pre-treated samples, indicating $P$ limitation. In contrast, in midJuly 2002, no SRP depletion was recorded in Tvärminne, while about $60 \%$ of ammonium additions were abruptly depleted within Days 0 to 1 in N and NP samples (Fig. 2e,f).

\section{DOC and DON dynamics}

Direct daily measurements with the HTCO method suggested that natural bacterioplankton communities degraded the ambient (net) labile DOC pool within $1 \mathrm{wk}$, and linear regressions fitted to this declining period gave LDOC values ranging from $<1$ to $5 \%$ of total DOC in the Tvärminne experiments (Table 4). Similar values were found during the cruise at the end of July 2001. No important effects of different combinations of nutrients ( $\mathrm{N}$ or $\mathrm{P}$ ), glucose, flagellate or sunlight treatments on bacterial depletion of DOC were recorded in Tvärminne (comparison of linear regression slopes over the first week: $F$-test, $\mathrm{p}>0.35$ to 0.65).

The time courses of changes in DON in Tvärminne experiments indicated that it plays a more dynamic role than DOC. In June 2001, DON concentrations first decreased by 15 to $20 \%$ within 4 to $6 \mathrm{~d}$ in each treatment set, including the combined NP treatment extra photochemical DOM transformations possibly caused by parallel sunlight pre-treatment) (Table 4). Sunlight pre-treatment did not cause any significant changes in bulk DOC, DON or ammonium concentrations.

\section{Biomass responses}

During the summer minimum period in 2001, initial bacterial biomasses in Tvärminne DOM incubations $(<0.7 \mu \mathrm{m}$ pre-filtered samples) were 50 to $70 \%$ of the total indigenous bacterial biomass, respectively. During the late summer cyanobacterial bloom in 2002, the $<0.7 \mu \mathrm{m}$ bacterial samples accounted for only $20 \%$ of the total biomass, because about $70 \%$ of the bacteria were either filamentous or attached to cyanobacterial clumps. The bacterial biomasses increased during incubations, showing peak values 3 to $7 \mathrm{~d}$ after the start (Fig. 3). After Day 7, heterotrophic nanoflagellates appeared in all samples, estab-

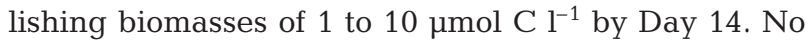
important treatment effects on bacterial net growth (biomass increase from start to peak value; 2-way ANOVA, p > 0.11 to 0.49 ) were observed, except for glucose addition to the $\mathrm{N}$ - and P-replete $\mathrm{NP}+\mathrm{C}$ (7 d) samples on Day 7, which led to a significant biomass response by Day 11 (Scheffé's F contrast test vs. all 


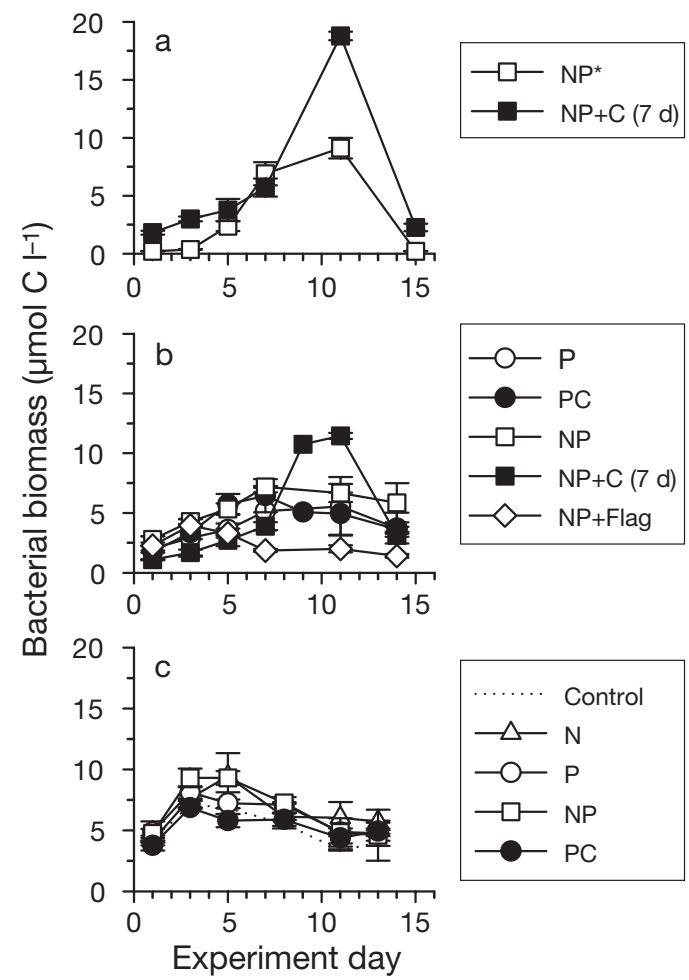

Fig. 3. Effects of different combinations of inorganic nutrients, glucose and flagellate treatments on time courses of bacterial biomass in DOM biodegradation incubations carried out in Tvärminne during the summer minimum period in 2001 (midJune: $a$; early July: b) and during the cyanobacterial bloom in 2002 (mid-July: c). Error bars = range $(\mathrm{n}=2)$; other explanations in Table 1

other treatment sets, $\mathrm{p}<0.05)$ in samples from early summer 2001.

\section{Bacterial production}

Judging from bacterial production and biomass responses, the most labile fractions of the indigenous DOM pools were used up within 1 wk (Figs. 3 to 5). Thus, net integral bacterial production values (start values subtracted) over the initial ca. $1 \mathrm{wk}$ stimulation periods were used to evaluate bacterial responses. This approach avoided the masking effect of flagellate grazing on bacteria, and this first week period coincided with the declining phases of DOC and DON pools, reflecting again bacterial exhaustion of available LDOC and LDON substrates (Table 4).

In early July 2001, combined $\mathrm{N}$ and $\mathrm{P}$ treatments (NP, NP+C [7 d] and NP+Flag samples) (Table 1) showed 70 to $90 \%$ higher integral bacterial production responses than a single $\mathrm{P}$ addition (Scheffé's $F$ contrast test, $\mathrm{p}<0.0001$ ); however, this was not the case in midJuly 2002 (Fig. 4). Nevertheless, combined PC treat- ment led to the highest integral production responses in both experiments (Scheffé's F contrast test vs. all other treatments, $\mathrm{p}<0.0001$ ), showing a 2 - to 3 -fold increase compared to controls. Moreover, unlike for the other treatments, the positive PC treatment effect lasted over the whole incubation period in both experiments. Finally, in early July 2001, addition of glucose to NP enriched samples on Day $7\left(\mathrm{NP}+\mathrm{C} \quad\left[\begin{array}{ll}7 & \mathrm{~d}\end{array}\right]\right)$ samples) resulted in a 5-fold increase in bacterial production by Day 11 which was not seen with the other treatment sets (Scheffé's F contrast test, p < 0.0001) (Fig. 4a).

Sunlight pre-treatment of particle-free DOM samples clearly stimulated subsequent bacterial production responses. In early July 2001, sunlight exposure led to $69-115 \%$ larger integral production responses compared to the corresponding dark samples in Tvärminne) (Scheffé's F contrast test, p < 0.0001) (Fig. 5). Moreover, combined NP treatment also resulted in a significant integral production response (on average $30 \%$ higher than respective controls with no nutrient additions) and the samples with combined sunlight and NP treatment showed the highest integral production response (Scheffé's $F$ contrast test, $p<0.001$ ) (Fig. 5). During the cruise at the end of July 2001, integral $1 \mathrm{wk}$ bacterial production in NP-treated samples was in turn 14 to $38 \%$ higher in the samples with sunlight pre-treatment compared to dark controls (Scheffé's F contrast test, p < 0.0001).

The sunlight pre-treatment effects were probably underestimated: on average, $6 \%$ of total bacterial production in whole samples was found in the $<0.2 \mu \mathrm{m}$ pre-filtered DOM samples after sunlight pre-treatment, and hence bacteria evidently consumed labile compounds (released by photodegradation) along with the indigenous net LDOM pool. Nevertheless, similar bacterial production values were recorded after sunlight pre-treatment in both light samples and dark controls, suggesting that no serious extra bias in bacterial activity was introduced due to the sunlight exposure. Integral bacterial production over the ca. $10 \mathrm{~h}$ sunlight pre-treatment period accounted at most for $5 \%$ of the corresponding net sunlight effect (light vs. dark values) over subsequent $1 \mathrm{wk}$ production stimulation periods (Fig. 5), suggesting that the importance of bacterial contamination bias was small in these experiments.

Finally, the TdR conversion coefficients measured in our bacterial DOM bioassays ranged from $0.24-0.59 \times 10^{9}$ cells $(\mathrm{nmol} \mathrm{TdR})^{-1}$ in early July 2001 to $1.7-3.1 \times 10^{9}$ cells $(\mathrm{nmol} \mathrm{TdR})^{-1}$ in mid-July 2002 . Our conversion factors averaged $1.1 \times 10^{9}$ cells (nmol $\mathrm{TdR})^{-1}(\mathrm{CV}=94 \%, \mathrm{n}=13)$, which equals the grand mean of conversion factors, covering a wide variety of water bodies and plankton succession stages (Riemann et al. 1987). 

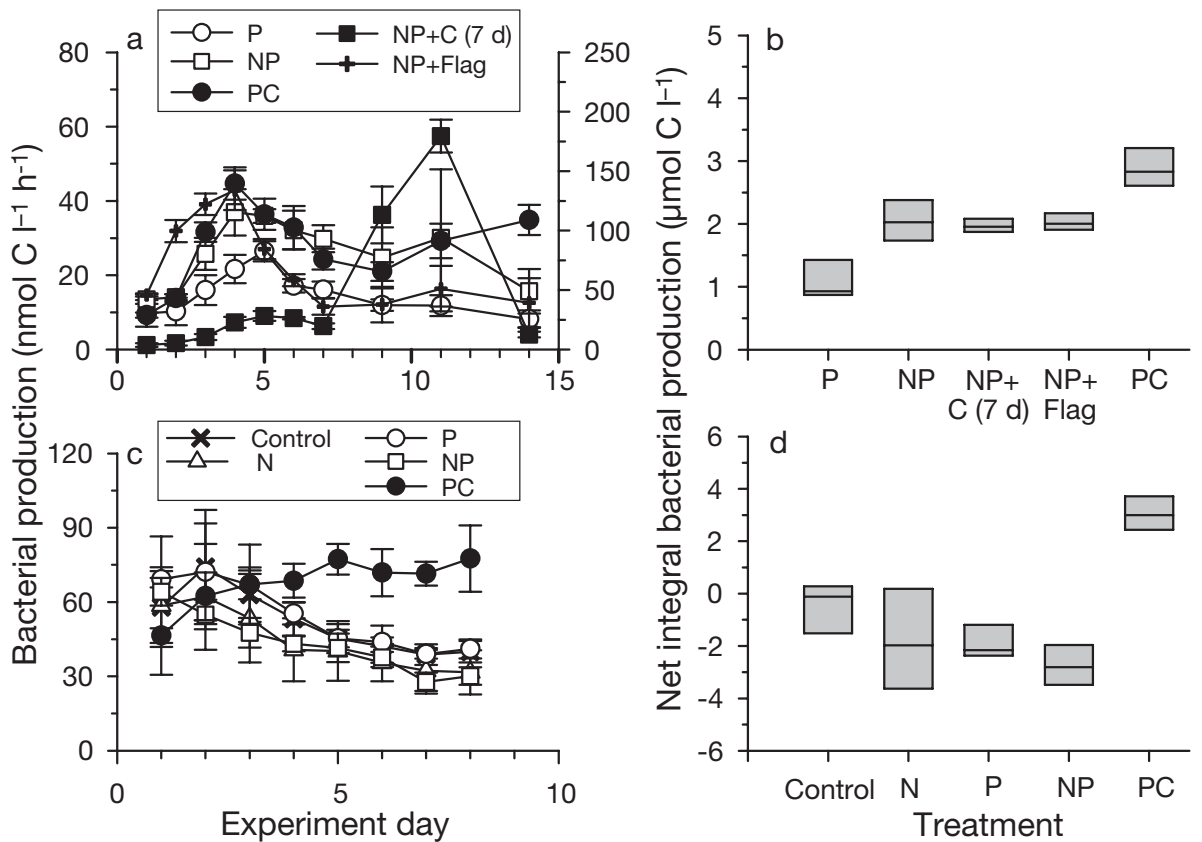

Fig. 4. Effects of inorganic nutrients, glucose, and flagellate treatments on time courses of $(\mathrm{a}, \mathrm{c})$ bacterial production and $(\mathrm{b}, \mathrm{d}) \mathrm{cor}-$ responding net integral production responses over the initial $1 \mathrm{wk}$ stimulation periods (box plots with 25th and 75th percentiles and median values, $\mathrm{n}=5$, start values subtracted) in DOM biodegradation incubations carried out in Tvärminne during the summer minimum period in 2001 (early July: a,b) and during the cyanobacterial bloom in 2002 (mid-July: c,d). With the NP+C (7 d) samples bacterial production is scaled to the right axis (a), while its glucose-C treatment on Day 7 does not show in net integral production over the first week (b). Error bars $=\mathrm{SD}$; other explanations in Table 1
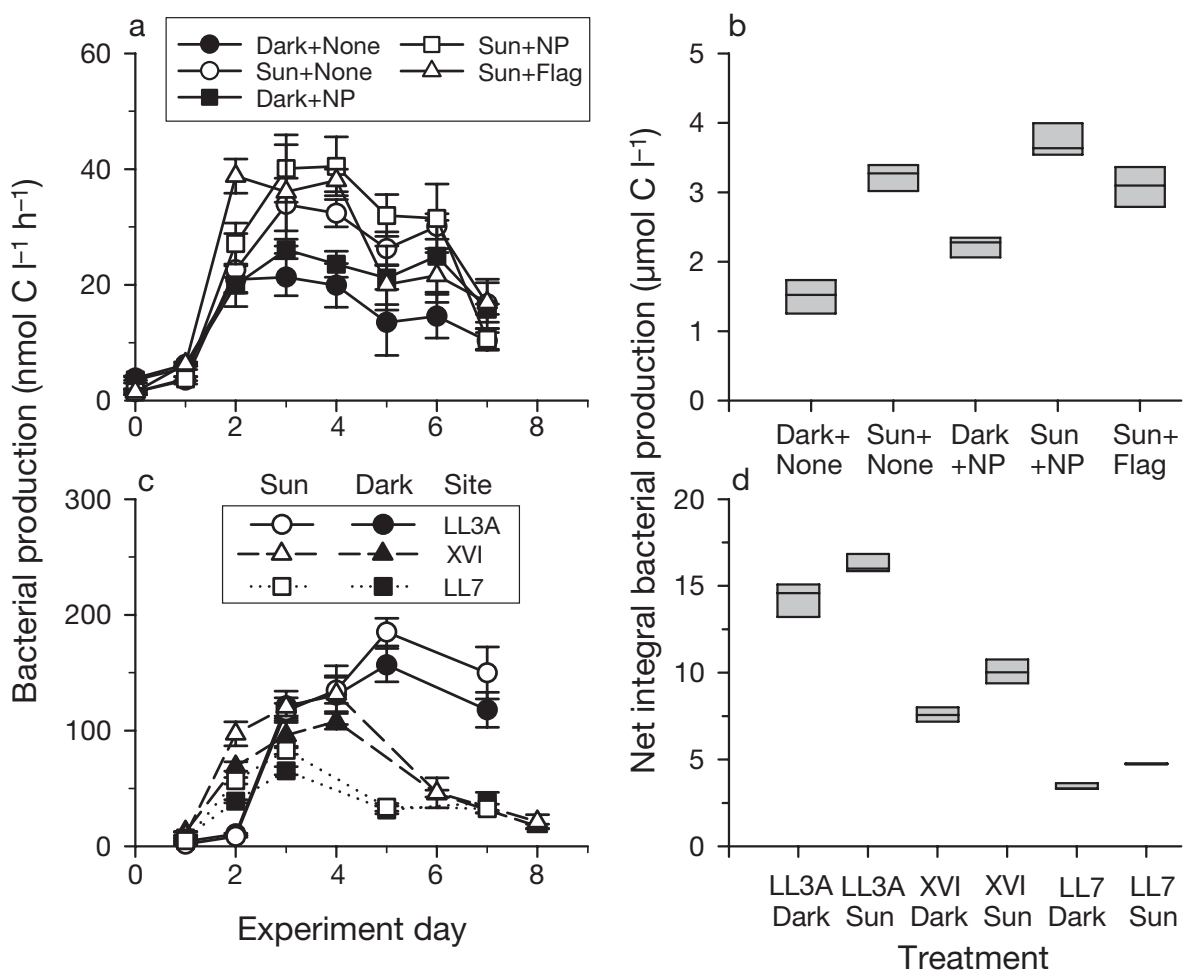

Fig. 5. Effects of sunlight (vs. dark) pre-exposure of DOM samples on time courses of bacterial production and corresponding net integral production responses over the initial $1 \mathrm{wk}$ stimulation periods (box plots) $(\mathrm{a}, \mathrm{b})$ in Tvärminne and (c,d) at 3 stations during the RV 'Aranda' cruise in the beginning and end of July 2001, respectively. The Tvärminne samples were subsequently treated with nutrients $(\mathrm{N}$ and $\mathrm{P}$ ) or flagellates (vs. control or none), while all cruise samples included NP treatment. Error bars = $\mathrm{SD}(\mathrm{n}=5)$ 


\section{DISCUSSION}

\section{Factors controlling bacterial growth}

During the summer minimum period, in June and early July 2001, the phytoplankton biomass was low in the Tvärminne area. The large winter pools of inorganic $\mathrm{N}$ were depleted by sedimenting spring bloom, while free phosphate was still available, resulting in low inorganic N:P ratios (about 2) compared to the Redfield ratio of 16 consistently found in marine particles (Redfield et al. 1963). These results strongly indicate that the phytoplankton system was N-limited (cf. Goldman 1980, Lignell et al. 1992, 2003, Kivi et al. 1993).

The depletion of ambient (net) labile DOC and DON pools was accompanied by stimulation of bacterial production and biomass development. In early July 2001, combined PC treatment led to the most important integral bacterial production response in the Tvärminne area. The ambient free SRP pool $\left(140 \mathrm{nmol} \mathrm{l}^{-1}\right)$ would have enabled a bacterial $\mathrm{C}$ biomass increase of about $6.4 \mu \mathrm{mol} \mathrm{l} \mathrm{l}^{-1}$, assuming a bacterial cell C:P ratio of 45 (Goldman et al. 1987). This net growth potential was larger than the realised bacterial $\mathrm{C}$ biomass increase (Fig. 3c), suggesting that bacteria were primarily Climited. Moreover, combined NP treatments resulted in significant integral bacterial production responses over the first incubation week when compared to single P treatment or Control samples (Figs. 4b \& 5b). This was evidently caused by ammonium addition under the prevailing P-replete conditions, supporting again the above view of an N-limited summer minimum period.

During the RV 'Aranda' cruise at the end of July 2001, ambient mineral pools of both $\mathrm{N}$ and $\mathrm{P}$ were small, and the concomitant high inorganic $\mathrm{N}: \mathrm{P}$ ratios (66 to 97) indicated that phosphorus was the primary limiting nutrient in the Gulf of Finland (cf. Goldman 1980, Gismervik et al. 1996). This view was supported by the results from combined NP treatments, in which only added phosphate was depleted by bacteria. By the end of July, a bloom of diazotrophic $\left(\mathrm{N}_{2}\right.$-fixing) filamentous cyanobacteria had emerged, which is capable of exploiting the extra free phosphate pool found in early summer and supplementing the productive surface layer with new N-rich substrates (Rolff 2000). The present results are in agreement with our earlier findings, showing a shift from N-limitation towards combined $\mathrm{N}$ and $\mathrm{P}$ deficiency with $\mathrm{P}$ as the primary limiting nutrient during late summer blooms of diazotrophic cyanobacteria (Lignell et al. 2003).

During the cyanobacterial bloom, in mid-July 2002, consistent moderate southwest-west winds caused an upwelling of nutrient-rich deep water, which is a frequently occurring phenomenon in the Tvärminne area
(Niemi 1975, Laanemets et al. 2004). The upwelling led to elevated mineral $\mathrm{N}$ and $\mathrm{P}$ concentrations and an inorganic N:P ratio (14) close to that of Redfield. Only the PC samples showed a significant positive bacterial response. We found no distinct $\mathrm{P}$ treatment effect and no concomitant SRP depletion in the PC samples, indicating $\mathrm{C}$ limitation of the bacterioplankton community during the mineral nutrient replete upwelling conditions.

In mid-July 2002, the initial bacterial biomass in our $<0.7 \mu \mathrm{m}$ pre-filtered sample accounted for only about $20 \%$ of the total bacterial biomass, because the major part of indigenous bacterioplankton was either filamentous or attached to cyanobacterial clumps. Cyanobacterial clumps are microbiotopes with high bacterial activity (Hoppe 1981), suggesting that an important component of the active bacterioplankton community was removed by $<0.7 \mu \mathrm{m}$ pre-filtering from our bioassays. Nevertheless, during a bloom of filamentous cyanobacteria in 2003, bacteria showed primarily Climitation in a bioassay using the whole plankton community (R. Lignell et al. unpubl. data). Thus, our results for samples taken during the mineral nutrient sufficient upwelling conditions in late summer 2002 seem to apply also to the whole bacterioplankton community, including the typical mineral $\mathrm{P}$ - and $\mathrm{N}$-deficient late summer bloom conditions in our study area (cf. Lignell et al. 2003).

\section{Biological role of DOC and DON}

Direct daily DOC measurements (HTCO method) showed that within the initial $1 \mathrm{wk}$ period of decline bacteria degraded $<1$ to $5 \%$ of total DOC. No significant treatment effects on LDOC values were recorded. Thus, our results supported similar results found in enclosed marine plankton communities with various nutrient ( $\mathrm{N}$ and $\mathrm{P}$ ) and glucose treatments by Søndergaard et al. (2000). Glucose addition on Day 7 to the $\mathrm{NP}+\mathrm{C}$ (7 d) samples (NP treatment on Day 0) led to significant increases in bacterial biomass and production by Day 11. This suggested, in turn, that the end of the bacterial production and biomass stimulation phase after the first week of incubation indeed mainly reflected exhaustion of labile carbon and energy sources in the $\mathrm{N}$ - and P-replete samples, rather than a deficiency in micronutrients (e.g. Fe) or enhanced grazing by flagellates.

During the early summer minimum period, the LDOC values were close to the detection limit for the HTCO method. To supplement these direct measurements, the LDOC pool was also estimated based on the bacterial biomass increase from start to peak on Days 3 to 7 (Fig. 3), allowing avoidance of the potentially seri- 
ous grazing bias caused by flagellate communities, which emerged after Day 7. Thus, total bacterial LDOC consumption was estimated by correcting the maximal bacterial $\mathrm{C}$ biomass increase for growth yield by dividing by 0.4 , which again represents the mean value for bacterial incorporation of freshly produced LDOC in enclosed marine plankton communities (SD 0.1; Søndergaard et al. 2000; cf. del Giorgio \& Cole 1998). Our estimates of bacterial C demand ( 2 to $5 \%$ of total DOC) corresponded well to the LDOC values measured directly with the HTCO method ( $<1$ to $5 \%$ ).

The share of LDOC was small in our study area compared to the average percentage LDOC of $19 \%$ reported for various marine surface waters (reviewed by Søndergaard \& Middelboe 1995). In previous studies conducted in other parts of the Baltic Sea the LDOC share was also larger, accounting for 4 to 10 and 9 to $17 \%$ of total DOC in the Bothnian Sea and in the Gulf of Riga, respectively (Zweifel et al. 1993, Zweifel 1999). On the other hand, our percentage and absolute LDOC values were similar to those found in shelf and basin waters of the western Arctic Ocean $(<1$ to $6 \%$ and 0.1 to $14 \mu \mathrm{mol} \mathrm{C} \mathrm{^{-1 }}$, respectively; Davis \& Benner 2007), and

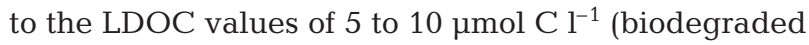
within $3 \mathrm{~d}$ ) found in enclosed plankton communities in a Norwegian fjord (Søndergaard et al. 2000).

The size of the LDOC pool is determined by the balance between its production and loss rates, and DOC harvested from different algal species and growth phases decomposes at very different rates (Chen \& Wangersky 1996, Søndergaard et al. 2000). Thus, the low percentage of LDOC suggested that bacteria efficiently exploit the available labile carbon and energy sources in the northern Gulf of Finland. This also possibly reflected ample availability of nutrients provided by deamination of the ambient labile DOM pool with low LDOC:LDON ratio (see biochemical interpretation of this ratio below) along with hydrolysis of various complexes and transformations of the abundant allochthonous colloidal and humic substances on the one hand, and high background concentrations of biologically recalcitrant allochthonous DOM on the other (cf. Niemi 1975, Moran \& Zepp 1997, Thingstad et al. 1997, Azam 1998, Berman \& Bronk 2003, Vähätalo \& Zepp 2005, Davis \& Benner 2007).

In the summer of 2001, percentage LDON shares varied from 13 to $21 \%$ in the Gulf of Finland. Our LDON values were within the range from 4 to $29 \%$ of the total DON (mean 13\%) found in the Gulf of Riga region of the Baltic Sea (Jørgensen et al. 1999).

The turnover (exhaustion) time estimates for LDOC and LDON pools were both about $1 \mathrm{wk}$. The similarity in these estimates suggests that the $\mathrm{C}$ and $\mathrm{N}$ in these bacterial substrates were components of the same molecules. Dissolved combined and free amino acids are the most abundant recognized components of DON, and under sufficient availability they also are the most important N sources for aquatic bacteria (e.g. Jørgensen et al. 1999, Berman \& Bronk 2003, and references therein). The low ambient LDOC:LDON ratios ( $<1$ to 3.7$)$ in the western Gulf of Finland suggested again that the Ncontaining components of LDOM in the present study were richer in $\mathrm{N}$ than most amino acids (algal proteins show a theoretical C:N ratio of 3.8; Laws 1991). High urea concentrations ( $\mathrm{C}: \mathrm{N}$ ratio of 0.5 ) would lead to low LDOC:LDON ratio (see Berman \& Bronk 2003), but studies on urea uptake kinetics found only about $100 \mathrm{nmol}$ urea $\mathrm{N}^{-1}$ or $<1 \%$ of total DON in our study area in mid-summer (Tamminen \& Irmisch 1996).

In summer 2001, the phytoplankton system was consistently $\mathrm{N}$-deficient in the western Gulf of Finland, including the westernmost cruise station LL7 at the end of July. Nevertheless, the low ambient LDOC: LDON ratios $(<3.7)$ indicated contemporaneous C limitation of bacterioplankton, as bacteria exhibit reasonably strict cellular C:N ratios of 4 to 5 along with 50 to $70 \%$ respiration losses in LDOC uptake (cf. Goldman et al. 1987, Gismervik et al. 1996, Thingstad \& Lignell 1997, del Giorgio \& Cole 1998, Søndergaard et al. 2000). Thus, these findings explain the need for glucose addition to obtain an important bacterial production response in the present study, and in earlier investigations done in the Gulf of Finland, in post-spring bloom conditions (Lignell et al. 1992, Kuparinen \& Heinänen 1993).

In July 2002, $60 \%$ of ammonium additions were abruptly depleted within $1 \mathrm{~d}$, being channeled into the DON pool, and a similar, though less dramatic, Nexchange between these pools took place after a delay of 4 to $6 \mathrm{~d}$ in June 2001. Collos et al. (1992) found analogous results with batch cultures of the alga Synedra planctonica. Processes such as viral lysis, exoenzyme production and DON release via feeding by heterotrophic nanoflagellates were plausible candidates for the fast DON release recorded in 2 out of 3 experiments (Collos et al. 1992, Ward \& Bronk 2001, Berman \& Bronk 2003). However, presently these surprising findings remain at least in part unexplained (cf. Ward \& Bronk 2001).

\section{Effect of photochemical DOM degradation}

Our daily sunlight treatments were too short for significant photochemical degradation effects to be seen in bulk DOC and DON pools (cf. Jørgensen et al. 1999, Vähätalo \& Zepp 2005). Nevertheless, photochemical transformations of DOM caused by sunlight pre-treatment clearly stimulated bacterial production, supporting results from previous investigations on UV- 
induced photochemical degradation of DOM (Moran \& Zepp 1997, Koopmans \& Bronk 2002, Vähätalo \& Zepp 2005, Vähätalo \& Järvinen 2007). Sunlight pre-treatment led to a significant increase in integral bacterial production in the samples with NP additions in both Tvärminne and cruise experiments, in July 2001. These results again suggest that labile organic carbon compounds were released via photodegradation of DOM (see Moran \& Zepp 1997, Berman \& Bronk 2003).

The photolytic surface layer is 0.6 to $1.4 \mathrm{~m}$ deep for photoammonification in the Gulf of Finland (Vähätalo \& Zepp 2005). Assuming a vertical attenuation coefficient of $4.6 \mathrm{~m}^{-1}$ for photochemically active UV radiation (corresponding to $1 \mathrm{~m}$ penetration depth) and a linear relationship between absorbed radiation and photochemical release of bacterial substrates (cf. Vähätalo \& Zepp 2005), we estimated that the observed $14-115 \%$ increase in integral bacterial production caused by sunlight exposure at $0.2 \mathrm{~m}$ over the course of a sunny day would have corresponded to $8-63 \%$ average increase in the upper $1 \mathrm{~m}$ of the water column or about $1-6 \%$ production enhancement in the $10 \mathrm{~m}$ deep mixed layer in the Gulf of Finland.

\section{CONCLUSIONS}

The C:N ratio of bulk DOM was consistently 20 to 22 , clearly higher than the concomitant LDOC:LDON ratios of $<1$ to 7 . In addition, the $\mathrm{N}$ :P ratios of total $\mathrm{N}$ and P pools were consistently higher than that of Redfield, including the early summer period, when initial inorganic N:P ratios were low and the plankton system was $\mathrm{N}$-limited. Thus, these results demonstrate the poor indicator value of total nutrient ratios, traditionally used for identifying the limiting nutrient in monitoring campaigns, as their interpretation is hampered by the large pools of biologically recalcitrant DOC and DON pools in the northern Baltic Sea.

Both bacteria and algae are able to exoenzymatically hydrolyse dissolved organic nutrients and take up the small labile components (see Azam 1998, Berman \& Bronk 2003), but in natural conditions bacteria dominate the incorporation of these components, including amino acids and simple sugars (Ferguson \& Sunda 1984, and references therein). Our bioassays suggest that bacteria were primarily C-limited, and this view is supported by the accumulation of LDON relative to LDOC under the prevailing N-deficient conditions (cf. Goldman et al. 1987). In conclusion, our results fit to a scenario where bacteria were consistently limited by the low availability of LDOC, while phytoplankton exhausted the available free mineral nutrient pools, thereby creating a situation combining C-limited bacterial growth with mineral nutrient limited phytoplankton growth (cf. Thingstad \& Lignell 1997). The additional bacterial response to $\mathrm{N}$ treatments in some of these bioassays suggests some kind of co-limitation by $\mathrm{N}$ and LDOC. Such scenarios may be rooted in flexible bacterial stoichiometry, either in terms of physiological responses at the species level (Martinussen \& Thingstad 1987), or at the community level through the co-existence of species with different $\mathrm{C}$ and $\mathrm{N}$ requirements.

Acknowledgements. Thanks to Professor H. Kuosa for algal counts, and E. Salminen and M. Sjölund for brave laboratory assistance. F. Thingstad, S. I. Niemelä, H. Rita, and M. Laine provided relevant comments on the manuscript. The study was funded by the Academy of Finland, Walter and Andrée de Nottbeck Foundation and EU project DANLIM (EVK2001-00049), and it was carried out at the hospitable Tvärminne Zoological Station (University of Helsinki). The linguistic form of the manuscript was checked by M. Metzler.

\section{LITERATURE CITED}

Azam F (1998) Microbial control of oceanic carbon flux: the plot thickens. Science 280:694-696

Berman T, Bronk DA (2003) Dissolved organic nitrogen: a dynamic participant in aquatic ecosystems. Aquat Microb Ecol 31:279-305

> Bjørnsen PK, Kuparinen J (1991) Determination of bacterioplankton biomass, net production and growth efficiency in the Southern Ocean. Mar Ecol Prog Ser 71:185-194

> Børsheim KY, Bratbak G (1987) Cell volume to cell carbon conversion factors for a bacterivorous Monas sp. enriched from seawater. Mar Ecol Prog Ser 36:171-175

Chen W, Wangersky PJ (1996) Rates of microbial degradation of dissolved organic carbon from phytoplankton cultures. J Plankton Res 18:1521-1533

Collos Y, Döhler G, Biermann I (1992) Production of dissolved organic nitrogen during uptake of nitrate by Synedra planctonica: implications for estimates of new production in the oceans. J Plankton Res 14:1025-1029

Davis J, Benner R (2007) Quantitative estimates of labile and semi-labile dissolved organic carbon in the western Arctic Ocean: a molecular approach. Limnol Oceanogr 52: $2434-2444$

del Giorgio PA, Cole JJ (1998) Bacterial growth efficiency in natural aquatic systems. Annu Rev Ecol Syst 29:503-541

Eilola K, Stigebrandt A (1999) On the seasonal nitrogen dynamics of the Baltic proper biogeochemical reactor. J Mar Res 57:693-713

Ferguson RL, Sunda WG (1984) Utilization of amino acids by planktonic marine bacteria: importance of clean technique and low substrate additions. Limnol Oceanogr 29:258-274

Gismervik I, Andersen T, Vadstein O (1996) Pelagic food webs and eutrophication of coastal waters: impact of grazers on algal communities. Mar Pollut Bull 33:22-35

Goldman JC (1980) Physiological processes, nutrient availability, and the concept of relative growth rate in marine plankton ecology. In: Falkowski PG (ed) Primary productivity in the sea. Plenum Press, New York, p 179-194

Goldman JC, Caron DA, Dennet MR (1987) Regulation of gross growth efficiency and ammonium regeneration in bacteria by substrate C:N ratio. Limnol Oceanogr 32: $1239-1252$

Grasshoff K, Erhardt M, Kremling K (eds) (1983) Methods of seawater analysis, 2nd edn. Verlag Chemie, Weinheim

Haas LW (1982) Improved epifluorescence microscopy for 
observing planktonic microorganisms. Ann Inst Oceanogr 58:261-266

Hobbie JE, Daley RJ, Jasper S (1977) Use of nucleopore filters for counting bacteria by epifluorescence microscopy. Appl Environ Microbiol 33:1225-1228

Hoppe HG (1981) Blue-green algae agglomeration in surface water: a microbiotope of high bacterial activity. Kiel Meeresforsch (Sonderh) 5:291-303

> Jørgensen NOG, Tranvik L, Berg GM (1999) Occurrence and bacterial cycling of dissolved nitrogen in the Gulf of Riga, the Baltic Sea. Mar Ecol Prog Ser 191:1-18

Kivi K, Kaitala S, Kuosa H, Kuparinen J and others (1993) Nutrient limitation and grazing control of the Baltic plankton community during annual succession. Limnol Oceanogr 38:893-905

Koopmans DJ, Bronk DA (2002) Photochemical production of dissolved inorganic nitrogen and primary amines from dissolved organic nitrogen in waters of two estuaries and adjacent surficial groundwaters. Aquat Microb Ecol 26: 295-304

Kuparinen J, Heinänen A (1993) Inorganic nutrient and carbon controlled bacterioplankton growth in the Baltic Sea. Estuar Coast Shelf Sci 37:271-285

Laanemets J, Kononen K, Pavelson J, Poutanen EL (2004) Vertical location of seasonal nutriclines in the western Gulf of Finland. J Mar Syst 52:1-13

Laws EA (1991) Photosynthetic quotients, new production and net community production in the open ocean. DeepSea Res 38:143-167

Lignell R (1990) Excretion of organic carbon by phytoplankton: its relation to algal biomass, primary productivity and bacterial secondary productivity in the Baltic Sea. Mar Ecol Prog Ser 68:85-99

Lignell R, Kaitala S, Kuosa H (1992) Factors controlling phytoand bacterioplankton in late spring on a salinity gradient in the northern Baltic. Mar Ecol Prog Ser 86:273-281

Lignell R, Seppälä J, Kuuppo P, Tamminen T, Andersen T, Gismervik I (2003) Beyond bulk properties: responses of coastal summer plankton communities to nutrient enrichment in the northern Baltic Sea. Limnol Oceanogr 48:189-209

Martinussen I, Thingstad TF (1987) Utilization of N, P and organic $\mathrm{C}$ by heterotrophic bacteria. II. Comparison of experiments and a mathematical model. Mar Ecol Prog Ser 37:285-293

Massana R, Gasol JM, Bjørnsen PK, Blackburn NT and others (1997) Measurement of bacterial size via image analysis of epifluorescence preparations: description of an inexpensive system and solutions to some of the most common problems. Sci Mar 61:397-407

Moran MA, Zepp RG (1997) Role of photoreactions in the formation of biologically labile compounds from dissolved organic matter. Limnol Oceanogr 42:1307-1316

Niemi $\AA$ (1975) Ecology of phytoplankton in the Tvärminne area, SW coast of Finland. II. Primary production and environmental conditions in the archipelago and the sea zone. Acta Bot Fenn 105:1-73

Norland S (1993) Relationship between biomass and volume of bacteria. In: Kemp PF, Sherr BF, Sherr EB, Cole JJ (eds) Handbook of methods in aquatic microbial ecology. CRC Press, Boca Raton, FL, p 303-306

Obernosterer I, Benner R (2004) Competition between biological and photochemical processes in the mineralization of dissolved organic carbon. Limnol Oceanogr 49:117-124

Obernosterer I, Sempéré R, Herndl GJ (2001) Ultraviolet radiation induces reversal of the bioavailability of DOM to marine bacterioplankton. Aquat Microb Ecol 24:61-68

Redfield AC, Ketchum BH, Richards FA (1963) The influence of organisms on the composition of sea-water. In: Hill MN (ed) The sea, Vol 2. Wiley-Interscience, New York, p 26-77

Riemann B, Bjørnsen PK, Newell S, Fallon R (1987) Calculation of cell production of coastal bacteria based on measured incorporation of ${ }^{3} \mathrm{H}$-thymidine. Limnol Oceanogr 32 : $471-476$

Rolff C (2000) Seasonal variation in $\delta^{13} \mathrm{C}$ and $\delta^{15} \mathrm{~N}$ of size-fractionated plankton at a coastal station in the northern Baltic proper. Mar Ecol Prog Ser 203:47-65

Sharp JH, Peltzer ET, Alperin MJ, Cauwet G and others (1993) Measurement of dissolved organic carbon and nitrogen in natural waters: procedures subgroup report. Mar Chem 41:37-49

Smith DC, Azam F (1992) A simple, economical method for measuring bacterial protein synthesis rates in seawater using ${ }^{3} \mathrm{H}$-Leucine. Aquat Microb Ecol 6:107-114

Søndergaard M, Middelboe M (1995) A cross-system analysis of labile dissolved organic carbon. Mar Ecol Prog Ser 118: 283-294

Søndergaard M, Williams PJleB, Cauwet G, Riemann B and others (2000) Net accumulation and flux of dissolved organic carbon and dissolved organic nitrogen in marine planktonic communities. Limnol Oceanogr 45:1097-1111

Tamminen T, Irmisch A (1996) Urea uptake kinetics of a midsummer planktonic community on the SW coast of Finland. Mar Ecol Prog Ser 130:201-211

Thingstad TF, Lignell R (1997) Theoretical models for the control of bacterial growth rate, abundance, diversity and carbon demand. Aquat Microb Ecol 13:19-27

Thingstad TF, Hagström ^̊, Rassoulzadegan F (1997) Accumulation of degradable DOC in surface waters: Is it caused by a malfunctioning microbial loop? Limnol Oceanogr 42:398-404

Utermöhl H (1958) Zur Vervollkommnung der quantitativen Phytoplanktonmethodik. Mitt Int Verein Theor Angew Limnol 9:1-38

Vähätalo AV, Järvinen M (2007) Photochemically produced bioavailable nitrogen from biologically recalcitrant dissolved organic matter stimulates production of a nitrogenlimited microbial food web in the Baltic Sea. Limnol Oceanogr 52:132-143

Vähätalo AV, Wetzel RG (2004) Photochemical and microbial decomposition of chromophoric dissolved organic matter during long (months-years) exposures. Mar Chem 89: 313-326

> Vähätalo AV, Zepp RG (2005) Photochemical mineralization of dissolved organic nitrogen to ammonium in the Baltic Sea. Environ Sci Technol 39:6985-6992

- Ward BB, Bronk DA (2001) Net nitrogen uptake and DON release in surface waters: importance of trophic interactions implied from size fractionation experiments. Mar Ecol Prog Ser 219:11-24

Williams PJleB (1995) Evidence for the seasonal accumulation of carbon-rich dissolved organic material, its scale in comparison with changes in particulate material and the consequential effect on net $\mathrm{C} / \mathrm{N}$ assimilation ratios. Mar Chem 51:17-29

Zweifel UL (1999) Factors controlling accumulation of labile dissolved organic carbon in the Gulf of Riga. Estuar Coast Shelf Sci 48:357-370

> Zweifel UL, Norrman B, Hagström Å (1993) Consumption of dissolved organic carbon by marine bacteria and demands for inorganic nutrients. Mar Ecol Prog Ser 101:23-32

Zweifel UL, Wikner J, Hagström Å (1995) Dynamics of dissolved organic carbon in a coastal ecosystem. Limnol Oceanogr 40:299-305

Zweifel UL, Blackburn N, Hagström A (1996) Cycling of marine dissolved organic matter. I. An experimental system. Aquat Microb Ecol 11:65-77 